\title{
Innovations that changed Mammalogy: field fixation for transmission electron microscopy (TEM)
}

\author{
Carleton J. Phillips, Bernard Tandler, Robert M. Timm,* Suzanne B. Mclaren, and Hugh H. Genoways \\ Department of Biological Sciences, Texas Tech University, Lubbock, TX 68424, USA (CJP) \\ School of Dental Medicine, Case Western Reserve University, Cleveland, OH 44106, USA (BT) \\ Department of Ecology \& Evolutionary Biology and Biodiversity Institute, University of Kansas, Lawrence, KS 66045, \\ USA (RMT) \\ Section of Mammals, Edward O'Neil Research Center, Carnegie Museum of Natural History, Pittsburgh, PA 15206, USA (SBM) \\ University of Nebraska State Museum, Lincoln, NE 68588, USA (HHG) \\ *Correspondent: btimm@ku.edu
}

Our fifth selection on innovations that changed mammalogy actually is both a plea and an innovation. The plea is to train scientists to handle what they collect in the field with great care for the unknown future "other" scientists that follow. For this innovation, the plea is for using fixatives correctly in the field so that later laboratory-based histology and histochemical comparisons will be possible. Integral to this plea is the critically important need to obtain vouchers, particularly if tissue sample destruction is the norm. The true innovation considered here makes it possible to use field-fixed specimens in transmission electron microscopy (TEM) studies. TEM is a valuable, but currently underused, research tool in mammalogy.

Comparative ultrastructure is the type of research enabled by field fixation. It has value far beyond mammalogy inasmuch as it provides data critical for a deeper understanding of evolutionary mechanisms, divergence, and fundamental cytoarchitecture. Moreover, the coronavirus pandemic makes access to specimens suitable for TEM extremely important, particularly such tissues as salivary glands from bats and rodents (Tandler et al. 1998a, 1998b). Viral infections in mammals are commonly associated with salivary glands. The cytomegalovirus infection in the African grass mouse (Arvicanthus dembeensis) described by Tandler et al. (1998b) is an excellent example of the complex relationship between virus and salivary glands. The importance of such infections and the tissue-level response to these call new attention to zoonotic (animal-borne) disease and the practical value of being able to compare species (Tandler et al. 1998b; Allen et al. 2003; Wickliffe et al. 2003; Briggs et al. 2011). An understanding of the relationship between virus and reservoir requires comparative ultrastructural data.
In biological science, the concept of comparison is critical to the thought process that supports thinking about animals in an evolutionary context (Phillips 1996). To organismal biologists it is obvious that morphological comparisons among mammals are necessary, if one is to identify species. Consequently, comparative biology is a cornerstone to everything in mammalogy no less than in biology.

In the late 1960s, Phillips decided to test the hypothesis that salivary glands in bats vary histologically and the differences could be explained in dietary terms. Confirmation required the detection of evolutionary differences that could be assessed with optical microscopy. Although a few papers had been published on salivary glands of wild species of mammals (including opossums, rabbits, insectivorous bats, and hedgehogs), the absence of systematics as a foundation for making meaningful comparisons crippled the ability to make use of most of the published data (Young and van Lennep 1978). The good news is that our ability to sequence genomes means that we have lots of fresh data (Phillips et al. 2014).

At the University of Kansas, the late G. Lawrence Forman from 1963 to 1969 was using histology and histochemistry to study the stomachs of bats with different diets. He and his colleagues showed that structural differences in the gastric mucosa often were species-specific. After looking at salivary glands from about 15 bat species, it was clear that histological differences abounded among species and that at least some, but not all, of these differences correlated with diet (Phillips et al. 1977). What were these differences and what was their meaning if they did not correlate with diet in the broad sense of the terms-insectivory, frugivory, nectarivory, carnivory, and piscivory? Meanwhile, histochemistry as a technique and an appreciation of cellular structure-function complexes had

(C) The Author(s) 2021. Published by Oxford University Press on behalf of the American Society of Mammalogists, www.mammalogy.org. 
raced ahead of general histology. Unfortunately, fewer and fewer samples in the typical museum collection were useful for the new techniques because fixation was so poorly done that tissues rarely were useful for research (Phillips 2005).

By 1970, it was hypothesized that cellular ultrastructure would reveal divergences associated with evolution of diverse diets. However, it was necessary to prepare specimens in the field that could be used for TEM-based comparisons of mammals at the cellular level. Earlier analyses supported the expectation that TEM comparisons should reveal the true nature of the "differences" among species examined with optical microscopy. Fieldwork in 1970, 1971, and 1972, led by Phillips in Mexico attempted various techniques but failed to adequately fix tissues for subsequent TEM scans. Professor Don Fawcett of Harvard Medical School advised him that he should move on to something less daunting. Fawcett, one of the few medical scientists in the world who had experience with research on wild species of mammals, including bats, was convinced that perfusion and laboratory environment were mandatory, if one wished to obtain tissues suitable for TEM (Fawcett and Ito 1965; Phillips 2005). However, Phillips was convinced that there only were three interrelated problems-1) osmolality, which caused cells and mitochondria to swell and subsequently rupture; 2) glutaraldehyde, which was the primary component of the previous fixatives that worked fairly well in laboratory settings (but not in the field); and 3) storage of tissues while in the field without access to a laboratory, refrigeration, or even electricity was a specific core challenge.

The next trial involved modifying a fixative recipe (referred to as a "triple aldehyde," meaning that the fixative had paraformaldehyde, glutaraldehyde, and acrolein) developed by Bernard Tandler and his colleague Robert Kalt for use in laboratory fixation of delicate amphibian embryos (Kalt and Tandler 1971). The outcome was highly encouraging and Phillips described cellular evolution based in part on tissues that had been field-fixed and processed in the laboratory (Phillips et al. 1977; Phillips 1994, 2005). Since then, a multiple aldehyde fixative with dimethyl sulfoxide (DMSO) in a weak $(0.05 \mathrm{M})$ cacodylate buffer has been used in the field to prepare tissue samples from more than 200 species (Tandler et al. 1998a, 2001, 2006). In 1987, one of the original aldehydes, acrolein, was determined to be too dangerous to transport because it is highly flammable. The problem was solved when Phillips replaced the acrolein with 4\% paraformaldehyde (Fig. 1). By then Phillips and Genoways had legally but foolishly flown thousands of miles in small civilian aircraft or helicopters over jungles and mountains all the while babysitting containers of acrolein, which is better known as tear gas. Thus, it is currently recommended that a version of the TEM field fixative that is similar to a half-strength Karnovsky fixative (4\% glutaraldehyde in a $1 \mathrm{M}$ phosphate buffer solution) be used (Phillips 2005). Ironically, this modified fixative is both slightly better than the original with acrolein and slightly more dangerous because of the difficulty of safely making a $4 \%$ paraformaldehyde solution without a fume hood.

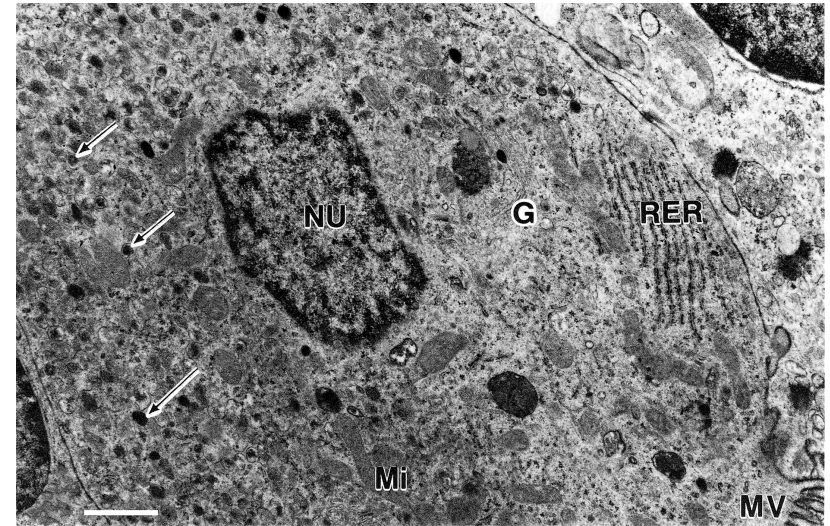

Fig. 1.-Transmission electron micrograph of a typical G-cell from the pylorus of the frugivorous bat Ariteus flavescens. Tissues of this endemic genus were fixed under field conditions on Jamaica in 1976. Arrows point to secretory granules. Abbreviations used for subcellular structures include: G, Golgi; Mi, mitochondria; MV, microvilli; NU, nucleus; RER, rough endoplasmic reticulum. The scale bar equals $0.83 \mu \mathrm{m}$. Adapted from Mennone et al. (1986:379).

As more and more ultrastructural data were obtained, the hypothesis that salivary glands were important in the evolution of mammalian diversity was repeatedly supported. Historically, these glands had been treated as minor players, so it was fortunate that the original hypothesis was based on possible differences among species in the structure of polarized regulated secretory cells (Phillips 1987). A big part of this type of research is finding the levels in the hierarchy at which speciation events occur and then being able to correlate them with branching pattern (Nagato et al. 1984; Phillips 1994, 1996; Tandler et al. 1997). Among species differences, it turned out that in some instances the differences were unique features in the sense that they were unknown in any other species; such an example occurs in the vampire bat (Desmodus rotundus) in which a unique cell type was found in the salivary gland excretory ducts. This is a cell "type" that produces and releases a protein-rich product (Tandler and Phillips 2003). New or unique organelles also have been found using field-fixed tissues; for example, in bats of the genus Lophostoma is a unique type of smooth endoplasmic reticulum (SER) in which the protein is crystallized into tubules (Nagato et al. 1984). The mitochondrial-nerve terminal complex is yet another unusual organelle found in a variety of bats in several families; however, the functions of these mitochondrial-nerve complexes remain unknown. Finally, there are the unique secretory granules containing layers of lipoprotein found in the bat genus Miniopterus (Tandler et al. 1994), representing a monotypic family of bats. Rare or commonplace is one of the questions that can be answered by survey work based on the ability to field fix tissues. Collectively, these discoveries illustrate the very rich potential of comparative cell ultrastructure as a foundation for future research.

This is the fifth in our series on innovations that have changed our science of mammalogy over its 150 -year history. The first three innovations (cyclone traps, Japanese mist nets, 
and dermestid beetles) have become part of the science or already have been replaced by successors. We have seen the impact of field techniques for karyotyping move from basics to being coupled with modern genomic analyses. Field fixation of specimens for TEM-based analyses shows substantial potential but so far has not been fully realized. One of the challenges is an artifact of how we train scientists. In universities, it is possible to earn a degree in a fairly narrow topic; however, for the person who can contribute in more than one field, such as mammalogy and cytology, the opportunities are substantial. For the first time, it is practical to combine ultrastructure with data on genes and gene expression. It will be great fun to watch the outcomes from these new data. The future could be now, at last.

\section{ACKNOWLeDgMents}

CJP expresses his thanks to his worthy field companions who put up with his focus on fixation and fixatives. In particular, he thanks HHG for his patience and tireless support. Funding for CJP's research came from many sources, including the NIH (NIDR) and university funding from Hofstra University and Texas Tech University. Paul Bowden, Lisa Miriello, and John Wible's efforts in reproducing the figure used herein are most appreciated.

\section{Literature Cited}

Allen, L. J., M. Langlais, And C. J. Phillips. 2003. The dynamics of two viral infections in a single host population with applications to hantavirus. Mathematical Biosciences 186:191-217.

Briggs, B. J., ET AL. 2011. Tick-borne encephalitis virus, Kyrgyzstan. Emerging Infectious Diseases 17:876-879.

FAWCETT, D. W., AND S. ITO. 1965. The fine structure of bat spermatozoa. The American Journal of Anatomy 116:567-609.

Kalt, R. M., AND B. TANDLER. 1971. A study of early amphibian embryos for electron microscopy. Journal of Ultrastructure Research 36:632-636.

Mennone, A., C. J. Phillips, And D. E. Pumo. 1986. Evolutionary significance of interspecific differences in the gastrin-like immunoractivity in the pylorus of phyllostomid bats. Journal of Mammalogy 67:373-384.

Nagato, T., B. Tandler, And C. J. Phillips. 1984. Unusual smooth endoplasmic reticulum in submandibular acinar cells of the male round-eared bat, Tonatia sylvicola. Journal of Ultrastructure Research 87:275-284.

Phillips, C. J. 1987. Mammalian evolution at the cellular level. Pp. 1-66 in Current mammalogy (H. H. Genoways, ed.). Plenum Press. New York.

Phillips, C. J. 1994. Anatomy. Pp. 234-257 in Seventy-five years of mammalogy (1919-1994) (E. C. Birney and J. R. Choate, eds.).
Special Publication of the American Society of Mammalogists no. 11. American Society of Mammalogists. Lawrence, Kansas.

Phillips, C. J. 1996. Cells, molecules, and adaptive radiation in mammals. Pp. 1-24 in Contributions in mammalogy: a memorial volume honoring Dr. J. Knox Jones, Jr. (H. H. Genoways and R. J. Baker, eds.). Museum of Texas Tech University. Lubbock.

Phillips, C. J. 2005. Ken Ward in the jungle: making scientific sense of field work. Pp. 85-128 in Going afield: lifetime experiences in exploration, science, and the biology of mammals (C. J. Phillips and C. Jones, eds.). Museum of Texas Tech University. Lubbock.

Phillips, C. J., G. W. Grimes, and G. L. Forman. 1977. Oral biology. Pp. 121-146 in Biology of bats of the New World family Phyllostomatidae, part III (R. J. Baker, J. K. Jones, Jr., and D. C. Carter, eds.). Special Publication no. 16. Museum of Texas Tech University. Lubbock, Texas.

Phillips, C. J., ET AL. 2014. Dietary and flight energetic adaptations in a salivary gland transcriptome of an insectivorous bat. PLoS ONE 9:e83512.

Tandler, B., E. W. Gresik, T. Nagato, and C. J. Phillips. 2001. Secretion by striated ducts of mammalian major salivary glands: review from an ultrastructural, functional, and evolutionary perspective. The Anatomical Record 264:121-145.

TANDler, B., T. NAGato, AND C. J. Phillips. 1997. Ultrastructure of the parotid gland in seven species of fruit bat in the genus Artibeus. The Anatomical Record 248:176-188.

Tandler, B., T. Nagato, K. Toyoshima, and C. J. Phillips. 1998a. Comparative ultrastructure of intercalated ducts in major salivary glands: a review. The Anatomical Record 252:64-91.

TANDler, B., AND C. J. Phillips. 2003. Ultrastructure of the submandibular gland of the rare white-winged vampire bat, Diaemus youngi. European Journal of Morphology 40:253-256.

Tandler, B., C. J. Phillips, and C. A. Pinkstaff. 1994. Mucous droplets with multiple membranes in the accessory submandibular glands of long-winged bats. The Anatomical Record 240:178-188.

TANDler, B., C. A. PinkstafF, AND C. J. Phillips. 2006. Interlobular excretory ducts of mammalian salivary glands: structural and histochemical review. The Anatomical Record. Part A, Discoveries in Molecular, Cellular, and Evolutionary Biology 288:498-526.

Tandler, B., Y. Seta, ANd C. J. Phillips. 1998b. Cytomegalovirus infection in the submandibular and parotid glands of the grass mouse, Arvicanthus. Journal of Submicroscopic Cytology and Pathology 30:207-215.

Wickliffe, J. K., V. H. Lee, E. Smith, B. Tandler, And C. J. Phillips. 2003. Gene expression, cell localization, and evolution of rodent submandibular gland androgen-binding protein. European Journal of Morphology 40:257-260.

Young, J. W., And E. W. VAN LenNeP. 1978. Morphology of salivary glands. Academic Press. New York.

Submitted 18 September 2020. Accepted 1 November 2020.

Associate Editor was Luis A. Ruedas. 